\title{
AN OPTIMUM CONDITION FOR ATTAINMENT OF A SINGLE CURRENCY PROJECT IN WEST AFRICA
}

The paper examines the primary and secondary convergence conditions for a monetary union in the second monetary zone for West Africa. The focus of the paper is on the primary conditions as they provide the basis for the secondary conditions. The annual panel data used for the research are obtained from the West African Monetary Agency website: www.wami.imao.org. The panel variables are first tested for unit root and stationarity. The panel unit root test results show that all the variables are integrated of order one. The stationarity test confirms the result, as the variables are non-stationarity in level but stationarity after first difference. The Long-run co integration equation is obtained using the pooled group mean estimator. Linear programming is then applied on the result of the long-run equationto obtain the optimal conditions for attainment of single currency project for West Africa. The result shows that the objective value of 0.0462 is obtained with inflation contributing more to the variation in the government external reserves. The Central Banks in West Africa should be cautious in implementing inflation targeting as a way of tackling their economic problem.

Key words: Convergence criteria; Linear programming; optimum condition; objective value; pooled group mean estimator

Chiawa, Moses Abanyam, Department of Mathematics/Computer Science, Benue State University, Makurdi, Nigeria, e-mail: abanymoses@yahoo.co.uk 


\section{Introduction}

The Economic Community of West African States (ECOWAS), is a regional body which was formed on May 28, 1975 with fourteen members. The main objective was to work towards a single currency leading to a single economic block (Masson and Pattillo, 2001). The countries that signed the treaty creating ECOWAS include the following: Benin Republic, Burkina Faso, Gambia, Ghana, Guinea Bissau, Guinea Conakry, Ivory Coast, Liberia, Mali, Niger, Nigeria, Senegal, Sierra Leone and Togo. Eight of these countries, Benin Republic, Burkina Faso, Guinea Bissau, Ivory Coast, Mali, Niger, Senegal and Togo are already operating a single monetary union, Union Économique et MonétaireOuest-Africaine (UEMOA) using a single currency, the franc de la CommunautéFinancière de l'Afrique (CFA franc), and a common central bank, the BanqueCentrale des Etats de l'Afrique de Ouest (BCEAO) (Benassy-Quere and Coudet, 2005).

The creation of a single monetary zone has been high on the agenda of the ECOWAS members since its inception in 1975 (Masson and Pattillo, 2001). To this end the following three primary objectives were formulated:

- Integration of monetary and fiscal policies to eventually create a common market,

- Creation of a single currency,

- Improve welfare of members through intra-regional trade (see Masson and Pattillo, 2001 for details).

Even though members were very enthusiastic at the formation of the regional body, and pursued these objectives with vigor, intra-regional trade could not be stimulated (Ojo, 2003). This has been blamed on the low volume of trade in the region (Itsede, 2002;Ogunkola, 2005). Similarly the objective to form a single monetary union for the entire region is still far away from being realized (Benassy-Quere and Coudet, 2005). Instead the five Anglophone countries Ghana, Nigeria, The Gambia, Guinea and Sierra Leone have gone ahead to initiate another monetary union tagged 'The West African Monetary Zone (WAMZ)' which will merge with the UEMOA after its take-off. Till date there is no assurance that even this single monetary zone for the five countries will take-off as proposed less the entire region.

Several dates tentatively fixed for the commencement of the WAMZ could not stand due to a number of factors which include the short time table for preparing a monetary union (see Itsede, 2002). A transition programme was put in place to commence in 2000 and terminate in December 2003, with the take-off date for the monetary union in July 2005, and merger date with UEMOA in 2006. These deadlines have slipped by, with the envisaged single currency project yet to commence. Nevertheless (because of the commitment 
to the realization of these goals) a new date December 1, 2015 has been fixed for the take-off of this monetary union (WAMA, 2009;Egwaikhide and Ogunleye, 2010).

Four primary and six secondary convergence criteria have been agreed upon. The targets and schedule of primary and secondary convergence criteria are shown in Table 1 and Table 2 below.

Table 1: Targets for Primary Convergence Criteria

\begin{tabular}{|l|l|}
\hline Criteria & Benchmark \\
\hline Inflation Rate & Single digit $(\leq 10 \%)$ \\
\hline Gross External reserves (Months of Imports & $\geq 3$ months \\
\hline $\begin{array}{l}\text { Central Bank Financing of Fiscal deficit as \% of Previous Tax's } \\
\text { Revenue }\end{array}$ & $\leq 10 \%$ \\
\hline Fiscal Deficit/Surplus/GDP (\%) Excl. Grants & $\leq \mathbf{4} \%$ \\
\hline
\end{tabular}

Table 2: Targets for Secondary Convergence Criteria

\begin{tabular}{|l|l|}
\hline Criteria & Benchmark \\
\hline Change in Domestic Arrears & $\leq 0 \%$ \\
\hline Tax Revenue/GDP ratio & $\geq 20 \%$ \\
\hline Salary Mass /Total Tax Revenue & $\leq 35 \%$ \\
\hline Exchange Rate (+:Depreciation/ -: Appreciation) & $\pm \mathbf{1 5} \%$ \\
\hline Real Interest Rate & $>0 \%$ \\
\hline Domestically Financed Investments/Domestic Revenue & $>20 \%$ \\
\hline
\end{tabular}

Available literature (WAMA, 2011) show that as at 2010 The Gambia satisfied two (2) primary and two (2) secondary conditions; Ghana satisfied three (3) primary and Zero (0) Secondary conditions; Guinea satisfied zero (0) primary and one (1) secondary condition; Nigeria satisfied two (2) primary and three (3) secondary conditions; while Sierra-Leone satisfied one (1) primary and one (1) secondary condition. Our focus is on the primary conditions stipulated above. This is because they are more difficult for a state controlled economy to attain.

\section{Theoretical framework}

The quantity theory of money explains the relationship between money supply and inflation. It states that there is direct relationship between quantity of money in an economy and prices of goods and services. In its simplest form 
the theory could be expressed as $\mathrm{MV}=\mathrm{PQ}$, where $\mathrm{M}$ is the money supply in an economy, $\mathrm{V}$ is the velocity of money in expenditures, $\mathrm{P}$ is the price level associated with transactions for the economy and $\mathrm{Q}$ is the real output.The equation assumes that $\mathrm{V}$ and $\mathrm{Q}$ are constant in short terms. This has however been criticized by prominent economists like Keynes, especially the assumption that $\mathrm{V}$ is constant (Catao and Terrones, 2003).

The criticisms above suggest the relaxation of the assumptions underlying the quantity theory of money. The relaxation allows for a broader analysis of the possible interactions among the variables in the identity. Thus, given that the percentage change in a product, say $\mathrm{U}$ and $\mathrm{V}$ which is equal to the sum of the percentage changes $(\Delta \mathrm{U}+\Delta \mathrm{V})$. The quantity theory could be rewritten in terms of percentage changes as $: \Delta \pi+\Delta \mathrm{Q}=\Delta \mathrm{M}+\Delta \mathrm{V}$. Rearrange the variables to get the identity:

$$
\Delta \mathrm{M}_{\mathrm{t}}=\Delta \pi_{\mathrm{t}}+\Delta \mathrm{Q}_{\mathrm{t}}-\Delta \mathrm{V}_{\mathrm{t}}
$$

Equation (1) implies that an increase in money supply leads to increase in inflation or output. In other words, a decrease in money supply leads to decrease in inflation or output. Thus a decrease in velocity or a combination of changes in these variables (depending on a number of factors) such as elasticity of supply and the level of unemployment in the economy concerned leads to increase in money growth or decrease in inflation.

The relationship between fiscal deficit to GDP ratio and inflation has been investigated by many authors including Catao and Terrones (2003), Bhattacharya (2009)andAmmama et al. (2011). A study conducted by Catao and Terrones (2003) for 23 countries found that a $1 \%$ reduction in ratio of fiscal deficit to gross domestic product (GDP)ratio lower long-run inflation by 1.5 to $6 \%$. They concluded that fiscal deficit is efficient determinant of inflation. Similarly, Bhattacharya (2009) tested the effect of fiscal deficit on inflation and concluded that any increase in demand caused by large deficit will raise prices. These studies did not investigate convergence, and the use the linear programming approach as adopted in this paper. Moreover, their focus was on long-run economic relationship between these variables.

The core issue under the ECOWAS monetary union is the convergence in microeconomic variablesas stated in the primary and secondary convergence criteria.In addition to facilitating policy coordination, it affords the opportunity to ensure microeconomic stability (WAMA, 2009). Available literature (WAMA, 2009;Egwaikhide and Ogunleye, 2010) shows that as at end of 2008 three primary criteria were satisfied except inflation whose average was 13.6 above the targeted value $(\leq 10 \%)$. It is sad to note that from here these countries could not maintain the momentum for which they used to satisfy these primary conditions.As demonstrated above, all the countries performed 
poorly in attaining the target set by the monetary agency. The five countries have to tighten their belts if not, the dream of a single currency come December 2015 will be a mirage.

The past has been very ugly for ECOWAS, in terms of implementation of set goals. None of the objectives of the regional body have been achieved on schedule. The region is still among the poorest in the world with weak institutions as reported in Benassy-Quere and Coudet (2005) and Roudet et al. (2007). The big question is 'can the goals of ECOWAS be achieved in the near future?'

Many solutions have been professed in the literature as documented by Ojo (2003), Itsede (2002), Obadan (2002), Ogunkola (2002), Masson and Pattillo (2001, 2003), Benassy-Quere and Coudet (2005), Ogunkola (2002, 2005) and WAMI $(2006,2007)$. Masson and Pattillo(2001) for instance argued in favour of genuine trade liberalization as a precondition for successful monetary unification with an independent single currency. Quoting from Hanink and Owusun (1998), and Yeats (1998), they observed that because of low market potentials, high transportation costs, similar factor endowments, liberalization might not be the solution. Itsede (2002) quoting from Corden (1972) emphasized the concept of monetary union as premised on two essential but interwoven parts. These include: exchange rate union which is an area in which exchange rates bear permanent relationship to each other and currency convertibility where exchange rate controls are permanently removed. Monetary union is then defined as the existence of a single monetary zone with a high degree of monetary stability in furtherance of economic integration (Itsede, 2002).

Other obstacles besides the conditions laid in the $\mathrm{OCA}^{1}$ theory that militate against monetary integration all over the world are lack of commitment, political will and strong leadership to implement the policies and actions that will move the programmes forward (Itsede, 2002). In West Africa, another factor is the non convertibility of the currencies of countries in the zone. Besides the UEMOA countries that already use the CFA Franc whose convertibility is backed by the French Treasury, all the other currencies (including the Nigerian naira) are not yet fully convertible. According to Obadan (2002), for a monetary union to be successful, the several currencies in the integrating zone must be fully convertible one into the other at permanently fixed exchange rates, thereby effectively creating a single currency. As stated earlier, the focus of the paper is to use the convergence criteria given at Table 1 to obtain an optimum convergence point for these economic

An Optimum Currency Area (OCA) is an area that maintains fixed exchange rate within their members, and flexible exchange rate with trading partners outside the area(Appleyard and Field, 1998).

Vol. 11, No 4, 2014: 109-128 
variables. This point is to serve as a point of convergenceto be satisfied by the primary conditions, hence this study.

Before monetary union is in place, conditions for its sustenance have to be in place. Implementing the monetary union before these primary and secondary convergence conditions are satisfied is like putting the cart before the horse, a major asymmetric shock would result in unbearable pressure within the union because of limited mobility and inadequate fiscal redistribution (Yuen, 2008). There is a common understanding that lasting economic convergence is a main prerequisite for a full monetary union. As such, significant degrees of convergence will have to be attained prior to monetary unification. The steps to be taken will be interdependent and will reinforce one another in particular the development of monetary unification, must be based on sufficient progress in the field of convergence and then the unification of economic policies (Yuen, 2008).Simulation studies by Solomon and De-Wet (2004) indicate that inflation is very responsive to shocks in budget deficit as well as GDP.

\section{Materials and methods}

\subsection{Data}

The data for this research was collected from the West African Monetary Agency (WAMA) in the website http://www.wami.imao.org. The annual data is for 10 years 2001 - 2010. The variables are: inflation rate $\left(\pi_{t}\right)$, ratio of fiscal deficit/surplus to GDP $\left(b_{t}\right)$, Central Bank financing of fiscal deficit $\left(d_{t}\right)$, and gross external reserves $\left(m_{t}\right)$. These data were collected for the five countries The Gambia, Ghana, Guinea, Nigeria and Sierra Leone.

\subsection{The Model Formulation}

Thestarting point of the model formulation is the empirical relationship between fiscal deficit, gross external reserve $(G)$ and inflation of a single equation model as given by Akçay et al. (2002),Vit (2003) and Solomon and De Wet (2004). Let us assume thatinflation $\left(\pi_{\mathrm{t}}\right) \leq \mathbf{0 . 1}$, gross external reserve $(\mathrm{G}) \geq$ $0.25 \mathrm{Imp}_{\mathrm{t}}$, where Imp $\mathrm{f}_{\mathrm{t}}$ annual imports, central bank financingof fiscal deficit $\leq \mathbf{0 . 1} T r_{t-1}$, where $T r_{t-1}$ is the tax revenue in the previous year and fiscal deficit to GDP ratio $(F d) \leq \mathbf{0 . 0 4}$. The equation linking fiscal deficit to GDP ratio $\left(\mathrm{Fd}_{\mathrm{t}}\right)$ with real interest rate $\left(r_{t}\right)$ is given by Vit (2003) as:

$$
r_{t}=c+F d_{t}+\varepsilon_{t}
$$


where $c$ is a constant and $\varepsilon_{t}$ is the random error.

However, similar to equation (1) Akcay et al. (2002) started with the following equation:

$$
G_{t}-\operatorname{Tr}_{t}+i_{t} B_{t-1}=\Delta M_{t}+\Delta B_{t}
$$

where $M_{t}$ is the reserve money, $B_{t}$ is total stock of domestic and foreign debt, $i_{t}$ is nominal interest rate, $G_{t}$ and $\operatorname{Tr}_{t}$ are already explained above. If the budget deficit is inclusive of interest payment then

$$
D_{t}^{*}=\Delta M_{t}+\Delta B_{t}
$$

where $D_{t}^{*}$ is the budget deficit. For countries with high inflation like those in WAMZ

$$
d_{t}+b_{t-1} \rho_{t}=\Delta b_{t}
$$

where $d_{t}$ is the primary deficit less reserve money with each variable scaled by nominal output $\mathrm{Y}, b_{t}$ is total stock of domestic and foreign debt at period $\mathrm{t}$, and $\rho_{t}$ is reserve money (see Akcay et al. 2002 for details).Equation (4) therefore follows that:

$$
b_{t-1}=\frac{1}{\left(1+\rho_{t}\right)}\left(b_{t}-d_{t}\right)
$$

The discounted debt-output ratio can be thus calculated using

$$
X_{t}=b_{t} \prod_{k=1}^{t}\left(1+\rho_{k}\right)^{-1}
$$

Taking logarithm transformation of equation (6) and rearranging leads to 


$$
\log \left(b_{t}\right)=\log \left(X_{t}\right)+\sum_{k=1}^{t}\left(\mathbf{1}+\rho_{k}\right)
$$

The starting point of the long run government budget constraint of Solomon and De Wet (2004) is:

$$
\frac{B_{t-1}}{P_{t}}=\sum \frac{1}{r_{j}}\left(\tau_{t+j}-g_{t+j}+\left(M_{t+j}-\frac{M_{t-j-1}}{P_{t+j}}\right)\right)
$$

where $\frac{B_{t-1}}{P_{t}}$ is government debt, $r_{j}$ is discount rate, $\tau_{t}$ is the tax revenue, $g_{t}$ is the government expenditure and $M_{t}$ is the broad money supply.Catao and Terrones (2003) derived a long-runequationthat explains the inflation rate by the budget deficit and money supply as:

$$
\pi_{t}=\alpha b_{t} \frac{p_{t}}{M_{t}}
$$

where $\alpha$ is the inverse linear multiplier, $b_{t}$ is the budget deficit which is $b_{t}=g_{t}-\tau_{t}-B_{t-1}$ and $\frac{M_{t}}{P_{t}}$ is the money supply.

Studies carried out by Vit (2003) found the relationship between real interest rate (discount rate) and budget deficit as follows:

$$
r_{t}=c+b_{t}+\varepsilon_{t}
$$

where $r_{t}$ is the real interest rate, $b_{t}$ is the budget deficit, $c$ and $\varepsilon_{t}$ are drift and residual terms respectively. Considering equations (5), (9) and (10), we have the functional form of the model given as: 


$$
m_{t}=\mathrm{f}\left(\pi_{t}, d_{t}, b_{t}\right)
$$

Linearly,equation (11) can be expressed as

$$
m_{t}=\phi_{1} d_{t}+\varphi_{2} b_{t}+\varphi_{3} \pi_{t}+\varepsilon_{t}
$$

where $\pi_{\mathrm{t}}$ is the inflation rate $\leq \mathbf{0 . 1}, b_{t}$ is the fiscal deficit/surplus/GDP ratio $\leq \mathbf{0 . 0 4}, \mathrm{d}_{\mathrm{t}}$ is Central Bank financing of fiscal deficit $\leq \mathbf{0 . 1}$, and $\mathrm{m}_{\mathrm{t}}$ is the gross external reserves $\geq \mathbf{0 . 2 5}$.

The long-run economic relationships between these variables are obtained by conducting the cointegration test. The long run cointegration equation is:

$$
\Delta y_{t}=\Pi y_{t-1}+\sum_{t=1}^{p-1} \Gamma_{j} \Delta y_{t-j}+x_{t}+\varepsilon_{t}
$$

where $y_{t}=\left(m_{t}, d_{t}, b_{t}, \pi_{t}\right)^{\prime}$ is a vector of endogenous variables, $x_{t}$ is a vector of exogenous (explanatory) variables which include deterministic terms and $\varepsilon_{t}$ is the residual error term.

This can beextended to the panel cointegration like the pooled mean group estimator of Persaran et al. (1999) given in section 3.4.

\subsection{Panel Unit Root Tests}

\subsubsection{Im, Pesaran and Shin test}

The Im, Pesaran and Shin (2003), test is based on N augmented DickeyFuller regressions:

$$
\Delta y_{i t}=\rho_{i} y_{i, t-1}+\sum_{j=1}^{p_{i}} \varphi_{i j} \Delta y_{i, t-j}+\alpha_{i}+\gamma_{i} t+u_{i t} \text { for } i=1, \ldots, N ; t=1, \ldots, T
$$


where $\mathrm{T}$ is the length of the sample, $\mathrm{N}$ is the cross-section dimension, $\Delta y_{i, t-j}$ are the lagged dependent variables included to eliminate serial correlation in the error term, $p_{i}$ are the country-specific lag lengths, $\alpha_{i}$ and $\gamma_{i}$ are country-specific intercepts (fixed effects) and trend parameters, respectively. The error term $u_{i t}$ is distributed as a white-noise random variable across $\mathrm{i}$ and $\mathrm{t}$, with $\mathrm{E}\left(u_{i t}\right)=0, \mathrm{E}\left(u_{i t}^{2}\right)=\sigma_{i}^{2}<\infty$ and $\mathrm{E}\left(u_{i t}^{4}\right)<\infty . p_{i}$, is assumed to be known and in practice it is estimated using an information criteria. The null hypothesis in the IPS test is $H_{0}: \rho_{i}=0$ for all $\mathrm{i}$, which implies that all individual series contain a unit root (are independent random walks). The alternative hypotheses assume that $H_{1 a}: \rho_{1}<0, \cdots, \rho_{N_{0}}<0$, and $H_{1 b}: \rho_{i}=0$ for $\mathrm{i}=N_{0}+1, \ldots, N$ (heterogeneous alternative). The IPS test averages the Augmented Dickey-Fuller statistics across groups to remove contemporaneous correlation in the errors. The statistic is given by:

$$
\bar{t}_{N T}=\frac{1}{N} \sum_{i=1}^{N} t_{i T}\left(p_{i}, \varphi_{i}\right) .
$$

This statistic converges sequentially to normal distribution as $T \rightarrow \infty$ followed by $N \rightarrow \infty$, while the ratio $\frac{N}{T} \rightarrow \alpha>0$, where $\alpha$ is a constant (see Lukacs, 1975). IPS compute the values $E\left[t_{i T}\left(p_{i}, \varphi_{i}\right)\right]$ and $\operatorname{Var}\left[t_{i T}\left(p_{i}, \varphi_{i}\right)\right]$ and propose a statistic which tends asymptotically to the standard normal distribution.

$$
W_{\bar{t}}=\frac{\sqrt{N}\left[\bar{t}_{N T}-N^{-1} \sum_{i=1}^{N} E\left[t_{i T}\left(p_{i}, 0\right) \mid p_{i}=0\right]\right]}{\sqrt{N^{-1} \sum_{i=1}^{N} \operatorname{Var}\left[t_{i T}\left(p_{i}, 0\right) \mid p_{i}=0\right]}} \underset{\underset{T, N \rightarrow \infty}{d}}{\longrightarrow} N(0,1)
$$

In practice, IPS test has been used recommended for use in many empirical applications (see for example Al-Rabbaie and Hunt, 2004; Aslan, 2008). 


\subsubsection{The Hadri test}

The test proposed by Hadri (2000) is a residual-based Lagrange Multiplier test (LM) in the spirit of the KPSS test suggested by Kwiatkowski et al. (1992). The Hadri test has a reverse null hypothesis, i.e. that the time series for each cross-section unit is stationary around a deterministic level or trend, against the alternative hypothesis of a unit root. It is based on the following regression:

$$
y_{i t}=\alpha_{i}+\gamma_{i} t+\sum_{t=1}^{T} u_{i t}+\varepsilon_{i t}
$$

where $\alpha_{i}$ and $\gamma_{i} t$ are the deterministic terms defined in (16) above, and the error term has two components: $\varepsilon_{i t}$ which is white noise, and $\sum_{t=1}^{T} u_{i t}$ which is a random walk. Under the null hypothesis $H_{0}: \sigma_{u}^{2}=0$ versus alternative hypothesis $H_{1}: \sigma_{u}^{2}>0$. That is the null hypothesis is that the variance of the random walk component $\left(\sigma_{u}^{2}\right)$ is zero. The autocorrelation in $\varepsilon_{i t}$ is accounted for by considering the long-run variances of the $\varepsilon_{i t}$ which is estimated by

$$
\hat{\sigma}_{\hat{\varepsilon}_{i}}^{2}=\frac{1}{T-1} \sum_{t=2}^{T} \hat{\varepsilon}_{i t}^{2}+2 \sum_{j=1}^{\bar{k}} w_{\bar{k} j}\left(\frac{1}{T-1} \sum_{t=j+2}^{T} \hat{\varepsilon}_{i t}^{\prime} \hat{\varepsilon}_{i, t-j}\right)
$$

where $w_{\bar{k} j}$ are weights used to ensure that $\hat{\sigma}_{\hat{\varepsilon}_{i}}^{2}$ are always positive. These Bartlett weights are given by $w_{\bar{k} j}=1-\left(\frac{j}{\bar{k}+1}\right)$, where $\mathrm{k}$ is the bandwidth. The $\mathrm{k}$ has to be efficiently chosen in order to get reasonable results. The statistic $H_{0}$ is the average of the individual KPSS statistic for each series. The test statistic is standardized to take the form $\frac{\sigma_{u}^{2}}{\sigma_{\varepsilon}^{2}}$, which has a standard normal distribution under the null hypothesis. 


\subsection{The Pooled-Mean Group Estimator}

The test for panel ARDL as proposed by Pesaran et al. (1999) is based on the pooled mean group estimator (PMGE). This allows for the short-run coefficients and error variances to differ across group, but constrains the longrun coefficients to be identical in an error correction framework. The pooled mean group estimator of order $\left(p_{i}, q_{i}\right)$ is given by the following equation

$$
\Delta y_{i t}=\phi_{i} y_{i t-1}+\beta_{i}^{\prime} x_{i t}+\sum_{j=1}^{p_{i}-1} \lambda_{i j} \Delta y_{i, t-j}+\sum_{j=0}^{q_{i}-1} \delta_{i j}^{\prime} \Delta x_{i, t-j}+\alpha_{i}+\varepsilon_{i t}
$$

where $y_{i t}$ is the dependent variable, $x_{i t}$ is vector of explanatory variables, $\alpha_{i}$ are country specific intercepts and $\lambda_{i j}$ and $\delta_{i j}$ are the country specific coefficients of the short-term dynamics, $\varepsilon_{i t}$ the white noise error term. The long-run coefficients $\phi_{i}=\phi$ (are defined to be the same across countries). If $\phi_{i}$ $<0$, there is a long-run relationship between $y_{i t}$ and $x_{i t}$ defined by $y_{i t}=-\left(\beta_{i}^{\prime} / \phi_{i}\right) x_{i t}+\eta_{i t}$. The maximum likelihood procedure based on the concentrated likelihood function is used to estimate the PMGE. A GaussNewton algorithm is used to maximize the likelihood function. The pooled mean group regression equation (23) can be estimated with individual specific $\phi_{i}$ which are then averaged over $\mathrm{N}$ to obtain a PMGE.

\subsection{Linear Programming Formulation}

The model formulated in equation (12) can be expressed as a linear programming as follows:

$$
\begin{aligned}
& \text { minimize } m_{t}=\phi_{1} d_{t}+\varphi_{2} b_{t}+\varphi_{3} \pi_{t} \\
& \text { subject to } \pi_{\mathrm{t}} \leq \mathbf{0 . 1} ; \mathrm{b}_{\mathrm{t}} \leq \mathbf{0 . 0 4} ; \quad \mathrm{d}_{\mathrm{t}} \leq \mathbf{0 . 1} ; \mathrm{m}_{\mathrm{t}} \geq \mathbf{0 . 2 5} .
\end{aligned}
$$

The optimal solution is obtained by the use of the Simplex method as shown in Hillier and Lieberman (2001). 


\section{Resultsand discussions}

A preliminary step is taken to calculate the correlation matrix for the four variables. The result shows that government external reserve is most correlated with the fiscal deficit to GDP ratio.

$\left.\begin{array}{cccccc} & \pi_{\mathrm{t}} & \mathrm{b}_{\mathrm{t}} & & \mathrm{d}_{\mathrm{t}} & \mathrm{m}_{\mathrm{t}} \\ \pi_{\mathrm{t}} & 0000 & & & \\ \mathrm{~b}_{\mathrm{t}} & .1161 & 1.0000 & & \\ \mathrm{~d}_{\mathrm{t}} & .4206 & -0.2259 & 1.0000 & \\ \mathrm{~m}_{\mathrm{t}} & . .2657 & 0.4590 & -0.2846 & 1.0000\end{array}\right)$

4.1.Results of Panel Unit Root Tests

The variables are tested for panel unit root and panel stationarity using Im et al. (2003) and Hadri (2000) to determine their degree of integration and level of stationarity. The results of the panel unit root tests are given in Table 3 . The result shows that the variables are nonstationary in levels but stationary in first difference. An indication the variables are integrated of order 1.

Table 3: Panel Unit Root Tests

\begin{tabular}{|l|l|l|l|l|}
\hline & \multicolumn{2}{|c|}{ IPS-W-test } & \multicolumn{2}{c|}{ Hadri-test } \\
\hline Variable & No trend & Trend & No trend & Trend \\
\hline$m_{t}$ & $-1.31(0.09)$ & $-0.04(0.48)$ & $2.65(0.00)$ & $4.13(0.00)$ \\
\hline$\Delta m_{t}$ & $-2.76(0.003)$ & $-1.02(0.155)$ & $0.95(0.17)$ & $3.34(0.00)$ \\
\hline$\pi_{t}$ & $-1.19(0.12)$ & $-0.12(0.45)$ & $0.97(0.17)$ & $3.79(0.00)$ \\
\hline$\Delta \pi_{t}$ & $-1.45(0.07)$ & $-0.28(0.39)$ & $0.16(0.44)$ & $0.12(0.45)$ \\
\hline$d_{t}$ & $-1.99(0.02)$ & $-0.55(0.29)$ & $2.53(0.01)$ & $6.68(0.00)$ \\
\hline$\Delta d_{t}$ & $-3.28(0.0005)$ & $-2.57(0.005)$ & $1.25(0.11)$ & $7.82(0.00)$ \\
\hline$b_{t}$ & $0.203(0.58)$ & $0.57(0.72)$ & $1.96(0.03)$ & $5.19(0.00)$ \\
\hline$\Delta b_{t}$ & $-0.83(0.204)$ & $0.02(0.51)$ & $2.51(0.01)$ & $13.08(0.00)$ \\
\hline
\end{tabular}

The IPS - $\mathrm{w}$-test at $5 \%$ are: for $\mathrm{N}=5, \mathrm{~T}=50$. The numbers in parentheses are the $\mathrm{p}$-values. 


\subsection{Panel Cointegration Results}

The results of the long-run cointegration parameters using the PMGE are given in Table 4 . The result of the long-run panel cointegration test shows that the variables inflation rate, fiscal deficit/surplus to GDP ratio account for most of the gross external reserves in agreement with the results of Catao\&Terrones (2003).

Table 4: Estimation Results of PMGE

\begin{tabular}{|l|l|l|}
\hline $\begin{array}{l}\text { Variables } \\
\text { Dep. var } m_{t}\end{array}$ & PMGE & t-value \\
\hline$\pi_{t}$ & 0.4437 & 4.48 \\
\hline$d_{t}$ & -0.072 & 0.24 \\
\hline$b_{t}$ & 0.0288 & 2.78 \\
\hline
\end{tabular}

Central Bank financing of the fiscal deficit however, did show little influence on the gross external reserves with a low t- ratio of 0.24 . The long-run panel cointegration relation using the PMGE with individual constants is

$$
e c_{t}^{m_{t}}=\mathbf{0 . 4 4 3 7} \pi_{t}+\mathbf{0 . 0 2 8 8} b_{t}-\mathbf{0 . 0 7 2 0} d_{t}
$$

Equation (4) shows that a $1 \%$ increase in government external reserves $\left(\mathrm{m}_{\mathrm{t}}\right)$ induces $0.4437 \%$ inflation rate $\left(\pi_{\mathrm{t}}\right)$. Similarly, a $1 \%$ increase in $\mathrm{m}_{\mathrm{t}}$ will induce a $0.0288 \%$ increase in the fiscal deficit to GDP ratio, and $-0.0720 \%$ decrease in the Central Bank financing of fiscal deficit. This result compares favorably with Solomon and de Wet (2004) whose simulation study showed that inflation is very responsive to shocks in budget deficit as well as GDP.

\subsection{The Optimum Convergence Criteria}

The objective value of the optimum convergence criteria is 0.0452 . The objective value for the variables, objective coefficients and their objective value contribution are given in Table 5. Inflation is the highest contributor to the optimum value followed by Central Bank financing of fiscal deposit, while fiscal deficit to GDP ratio is the least. 
Table 5: The Optimum Convergence Criteria

\begin{tabular}{|l|l|c|c|c|}
\hline Variables & Value & $\begin{array}{c}\text { Objective } \\
\text { Coefficient }\end{array}$ & $\begin{array}{c}\text { Objective Value } \\
\text { Contribution }\end{array}$ & Slack-/Surplus+ \\
\hline$m_{t}$ & 0.25 & 0.00 & 0.0000 & 0.0000 \\
\hline$\pi_{t}$ & 0.10 & 0.44 & 0.0440 & 0.0000 \\
\hline$d_{t}$ & 0.00 & 0.03 & 0.0012 & 0.0000 \\
\hline$b_{t}$ & 0.04 & -0.07 & 0.0000 & 0.1000 \\
\hline
\end{tabular}

\section{Conclusion}

The conclusion we draw from the paper is that Government external reserves, inflation rate, fiscal deficit/GDP ratio, Central Bank financing of fiscal deficit are correlated with the highest correlation between government external reserves and fiscal deficit and GDP ratio. Theresult shows that the objective value of 0.0462 is obtained with inflation contributing more to the variation in the government external reserves at variance with the correlation matrix. This may be due to the non-stationarity of the variables in level. Due to the result of linear programming approach,we advise that Central Banks in the countries studiedto be cautious in implementing inflation targeting as a way of tackling their economic problems. In conclusion there is a warning by Solomon and De Wet (2004) that governments should note the sensitivity of price levels to fiscal policy.

\section{Literature}

- Al-Rabbaie, A. and Hunt, C. (2004), Panel Unit Roots and Cointegration: Evidence for OECD Energy Demand, $6^{\text {th }}$ IAEE European Conference on Modelling in Energy Economics and Policy, 2-3 September, 2004.

- Ammama, Mughal, K \& Khan, M. A. (2011). Fiscal Deficit and its Impact on Inflation, Causality and Cointegration: The Experience of Pakistan (1960-2010), Far East Journal of Psychology and Business, 5(3): 51 - 62.

- Aslan, A. (2008), Testing Gibrat's Law: Empirical Evidence from Panel Unit Root Tests of Turkish Firms, International Research Journal of Finance and Economics, 16: 137-142. 
- Bénassy-Quere, A. and Coupet, M. (2005), On the Adequacy of Monetary Arrangements in Sub-Saharan Africa, The World Economy, 28(3): 349-373.

- Bhattacharya J (2009, Aug 21), "The Fiscal Deficit"

- Catao, L. \&Terrones, M. E. (2003). Fiscal Deficits and inflation, Washington, IMF, Working Paper No. 65/03.

- Catao, L. and Terrones, M.E. (2005). Fiscal Deficits and Inflation.Journal of Monetary Economics, 52(3): 529-554.

- Corden, W. M. (1972), Monetary Integration, Essays in International Finance, Princeton, New Jersey, Princeton University, Octavo, Card wraps.

- Egwaikhide, F. O. and Ogunleye, E. K. (2010). Globalisation and Macroeconomic Convergence in the WAMZ, West African Journal of Monetary and Economic Integration, 10(1): 89 - 130.

- Hadri, K. (2000). Testing for Unit Roots in Heterogeneous Panel Data, Econometrics Journal, 3: 148-161.

- Hanink, D. and Owusun, J. H. (1998). Has ECOWAS Promoted Trade Among Its Members? Journal of African Economies, 7 (3): 363-383.

- Hillier, F. S. and Lieberman, G. J. (2001). Introduction to Operations Research, 7th Ed. McGraw-Hill Companies, Inc.

- Im, K., Pesaran, H. and Shin, Y. (2003). "Testing for Unit Roots in Heterogenous Panels," Journal of Econometrics, 115: 53 - 74.

- Itsede, C. O. (2002), The Challenge of Monetary Union: Gains and Opportunities, Central Bank of Nigeria Economic and Financial Review, 40(4) 49-65.

- 15 Kwiatkowski, D., Phillips, P.C.B., Schmidt, P. and Shin, Y. (1992). "Testing the Null Hypothesis of Stationarity Against the Alternative of a Unit Roolt," Journal of Econometrics, 54: 159-178.

- Masson, P. and Pattillo, C. (2001), "Monetary Union in West Africa (ECOWAS)." International Monetary Fund Occasional Paper No. 204.

- Masson, P. and Pattillo, C. (2003), "Monetary union in West Africa: An Agency of Restraint for Fiscal Policies?” Journal of African Economies, 3(11): 387-412. 
- Obadan, M. I. (2002), Exchange Rate Mechanism Under The West African Monetary Zone, Central Bank of Nigeria Economic and Financial Review, 4(40): 149-165.

- Ogunkola, E. O. (2002), The Second Monetary Zone in West Africa and The Future of a Single Monetary Zone in Sub-Saharan Africa, Paper Presented at Conference on "Towards Regional Currency Areas", Santiago, Chile, 2627 March, 2002, Retrieved 07.12.2006 from http://www.cepii.fr/anglaisgraph/meetings/2002/26270302.htm,

- Ogunkola, E. O. (2005), "An Evaluation of the viability of a Single Monetary Zone in ECOWeAS." African Economic Research Consortium (AERC), Research Paper 147. Nairobi.

- Ojo, M. O. (2003), Regional Currency Areas and The Use of Foreign Currencies: The Experience of West Africa, BIS Papers, 17: 140-144.

- Pesaran, M.H., Shin, Y. and Smith, R. P. (1999). Pooled Mean Group Estimation of Dynamic Heterogeneous panels, Journal of The American Statistical Association, 94: 621-624.

- Roudet, S., Sexagaard, M. and Tsangarides, C. (2007), Estimation of Equilibrium Exchange Rates in the WAEMU: A Robustness Approach, IMF Working Paper, Retrieved 07.08.2008 from http://www.imf.org/external/pubs/ft/wp/2007/wp07194.pdf.

- Solomon, M and de Wet, W. A. (2004). The Effect of Budget Deficit on Inflation: The Case of Tanzania, South African Journal of Economic and Management Sciences(SAJEMS) , 7(1): 100 - 116.

- Vit, K. (2003). The Possibilities of Budget Deficit Financing,Paper Presented at the $11^{\text {th }}$ NISPAcee Annual Conference, Bucharest Romania, April 10-12, 2003.Retrieved 24.06.2013.from

http://unpan1.un.org/intradoc/groups/public/documents/nispacee/unpan009154.pdf

- West African Monetary Agency (WAMA),(2009). Money Supply Growth and Macroeconomic Convergence in Ecowas Retrieved from http://www.wami-imao.org accessed on June 24, 2013.

- West African Monetary Agency (WAMA),(2011). Statistics.Retrieved 28.07.2013 from $h t t p: / / w w w . w a m i-i m a o . o r g /$ 
- West African Monetary Institute (WAMI), (2006), Quoting and Trading in WAMZ Local Currencies. Retrieved 11.02.2007 from http://www.wamiimao.org/english/doc/.pdf.

- West African Monetary Institute(WAMI), (2007). WAMZ NEWS A Quarterly Newsletter of the West African Monetary Institute 1(1).Retrieved 12.08.208 from http://www.wami-imao.org/english/doc/.pdf

- Yeats, J. A. (1998). What Can be Expected from African Regional Trade Arrangements?, Policy Research Working Paper No. 2004, November (Washington: World Bank). Retrieved 23.09.2008 from

http://www.worldbank.org/html/dec/Publications/Workpapers/wps2000series/wps2004/w ps2004.pdf

- Yuen, H (2008). Globalization and Single currency The Prospects of Monetary Integration in East AsiaRetrieved 12.04.2008 from http://econ.tu.ac.th/iccg/papers/hazel.doc

Paper received: September $17^{\text {th }}, 2014$

Approved for publication: September $30^{\text {th }}, 2014$
Rad primljen: 17. septembar 2014. Odobren za štampu: 30. septembar 2014. 


\section{Chiawa, Moses Abanyam}

Benue, državni institut za matematiku i kompjuterske nauke, Makurdi, Nigerija

\section{OPTIMALNI USLOVI ZA USPOSTAVLJANJE PROJEKTA ZAJEDNIČKE VALUTE U ZEMLJAMA ZAPADNE AFRIKE}

\section{S a ž e t a k}

Ova studija ispituje konvergenciju primarnih i sekundarnih uslova radi uspostavljanja zajedničke valute u drugoj valutnoj zoni zapadne Afrike. Osnovni focus ove studije je sagledavanje primarnih uslova, obzirom da su oni osnova iz kojih proizilaze sekundarni uslovi. Godišnji panel podaci korišćeni za ovo istraživanje su dobijeni sa vebsajta Z. Afričke Valutne agencije: www.wami.imao.org. Promenljive vrednosti Panela su prvo ispitane za jedinični koren i stacionarnost. Rezultati ispitivanja jediničnog korena panela pokazuju da su promenljive vrednosti integrisane $\mathrm{u}$ red veličine jedan. Test stacionarnosti potvrđuje taj rezultat, pošto su promenljive vrednosti nestacionarne u nivou, ali stacionarne posle prve razlike. Dugoročna kointegraciona jednačina se dobija korišćenjem procenitelja aritmetičke sredine ciljne grupe. Linearno programiranje se onda primenjuje na rezultat dugoročne jednačine kako bi se dobili optimalni uslovi za postizanje projekta zajedničke valute Z. Afrike. Rezultat pokazuje da objektivni rezultat od 0.0462 se dobija tako što inflacija doprinosi više promenljivosti u vladinim spoljnim rezervama. Centralne Banke $Z$. Afrike bi trebale biti obazrive u ciljanju inflacije kao mehanizma u borbi s ekonomskim problemina.

Klučne reči: Kriterijumi konvergencija; Linearno programiranje; Optimalni uslov; Objektivni rezultat; procenitelj aritmetičke sredine ciljne grupe 
